\title{
Geranylgeranyl Transferase Type-1 Subunit Beta
}

National Cancer Institute

\section{Source}

National Cancer Institute. Geranylgeranyl Transferase Type-1 Subunit Beta. NCI

Thesaurus. Code C41055.

Geranylgeranyl transferase type-1 subunit beta (377 aa, $\sim 42 \mathrm{kDa}$ ) is encoded by the human PGGT 1B gene. This protein plays a role in protein geranylgeranylation. 